\title{
A STATISTICAL STUDY OF THE VARIATION IN VERTICAL PLANKTON HAULS, WITH SPECIAL REFERENCE TO THE LOSS OF THE CATCH WITH DIVIDED HAULS
}

\author{
By H. Barnes \\ The Marine Station, Millport
}

(Plates I, II and Text-figs. I-6)

\section{INTRODUCTION}

Although in some branches of marine biology statistical methods have been extensively employed in considering the sampling variations so frequently encountered, little attention has yet been paid to the study of such variations arising in plankton work. Gardiner (I93I), and particularly Winsor \& Walford (1936), Winsor \& Clarke (I940) and Silliman (1946), have given some consideration to the problem, and an account of a freshwater plankton investigation in which the techniques were carefully chosen and the results critically examined by statistical methods has been given by Baldi, Cavalli and Pirocchi (1945). Early work by Hensen (I887, I900-I2), Lohmann (1903), and Herdman (I92I) indicated the order of variation to be expected in vertical hauls.

The material on which the following analysis is based was obtained by Marshall, Nicholls \& Orr and some of the results of the work have already been given (I934). A further account of the material has recently been given by Marshall (I949), where all the raw data dealt with here may be found. The discrepancy observed between the total catch in divided and undivided hauls was a puzzling feature of these results, and subsequent to discussions with Dr Marshall on the origin of this discrepancy she placed at my disposal for analysis the whole of the data. Thanks are due to Dr Marshall not only for providing the data but also for giving further details of the technique and circumstances of the collections. It is also a pleasure to acknowledge the assistance of Dr R. A. Robb, who read the manuscript at several stages of its preparation and who, by his critical comments and advice, has enhanced its value.

The material was all collected by means of a net hauled vertically. Some details of the work have been given in the references already cited, but since the analysis will be of use to other workers only if the conditions under which the hauls were made are precisely defined, the salient features of the technique must be summarized.

(i) The hauls were made with a modified international net fitted with a Nansen (1915) closing mechanism. The net differed from the standard 
pattern in the absence of a coarse net band above the canvas band carrying the throttling device.

(ii) Hauling was by hand winch.

(iii) The speed of hauling was controlled by timing the rate of haul (depth being followed by means of the metre wheel) with a stop-watch, instructions being shouted to the person working the winch. An attempt to maintain a hauling speed of $0.5 \mathrm{~m}$. $/ \mathrm{sec}$. was made.

(iv) The bucket used on the net was a simple metal cylinder tied on with string.

(v) After completion of the haul the catch was washed into the bottom of the net by moving the latter up and down in the water, without, of course, allowing the mouth of the net to go under the surface of the water.

(vi) The bucket was then carefully removed and the contents emptied into a breffit containing formalin. The bucket was then rinsed out several times with sea water from a pail and the washings added to the catch; the canvas portion at the base of the net was then turned back exposing the lower portion of the net and, with this held over the breffit, all obvious organisms were carefully removed and the whole washed down several times.

(vii) In taking the divided hauls an attempt was made to release the messenger so that the net would close at the selected depth without any interruption of the hauling.

(viii) The weather conditions under which the catches were made varied throughout the season; the stations worked were inside a comparatively sheltered sea loch and at no time during this particular series were the conditions very bad.

(ix) The depth of the haul was of the order of $60 \mathrm{~m}$., and its duration approximately $2 \mathrm{~min}$. If $5 \mathrm{~min}$. for removing the catch is allowed, this gives a period of about Io min. in which to obtain duplicate hauls.

(x) Counts of the developmental stages of the following copepods were made and have been used in the analysis: Pseudocalanus minutus (Krøyer), Microcalanus pygmaeus G. O. Sars, Centropages hamatus (Lilljeborg), Temora longicornis (Müller), Acartia clausi Giesbrecht, Oithona similis (Claus).

It should be stated that this work was not originally planned for statistical treatment, and a selection of the data will be presented to illustrate the problems involved and their possible solution.

\section{The Undivided HaUls}

Three pairs of duplicate undivided hauls will now be considered and the data are plotted as the log of the catches for the separate stages of each pair of hauls in Fig. I. In each of the catches eight stages of the six species were counted so that, neglecting those pairs in which the total number caught $\left(n_{1}+n_{2}\right)$ was less than 5, there are I34 pairs of observations, each stage of every species being 
considered independently. The results obtained with these undivided hauls will first be compared with the data analysed by Winsor \& Walford (1936) using counts of a series of catches of fish eggs (the E-S series) and the data obtained in the course of investigations of catching powers of different types of nets by Künne (I929, I933). The problem, as pointed out by these authors,

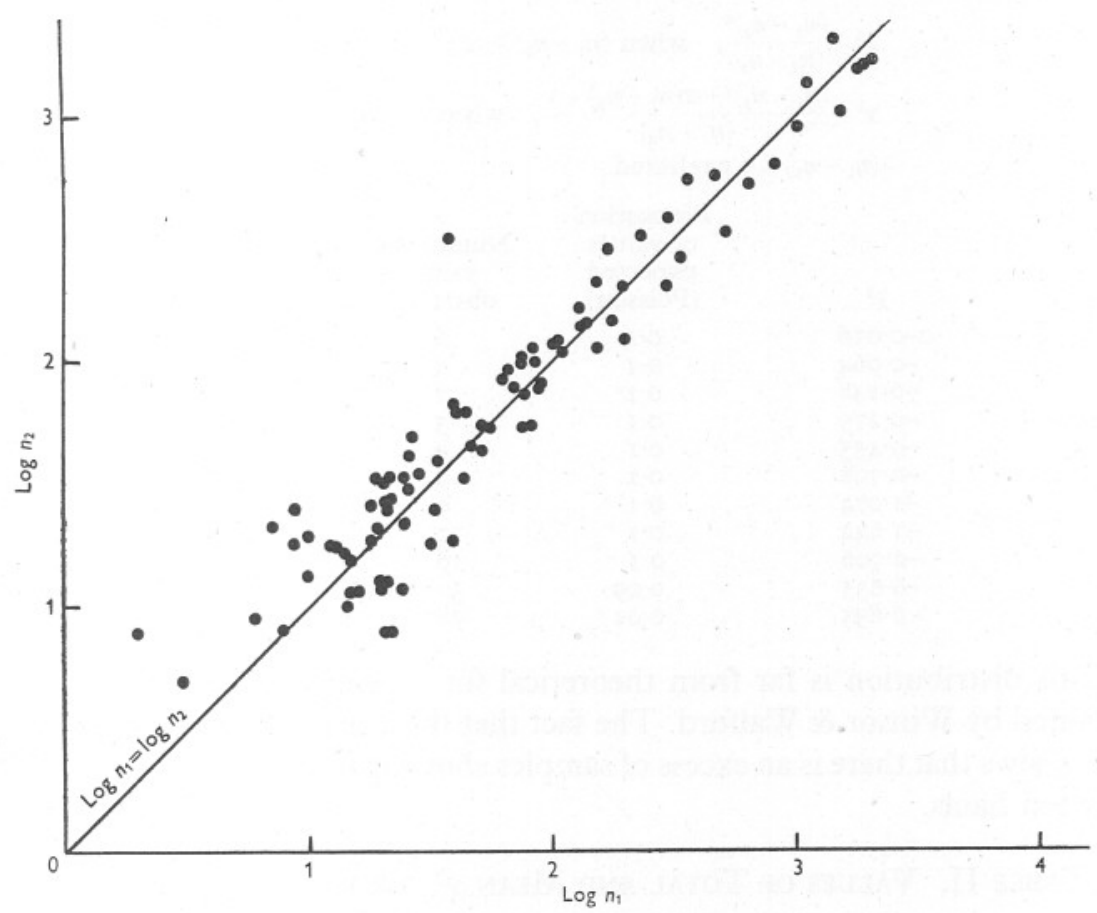

Fig. I. The relationship between pairs of catches of all stages of six copepods for three sets of duplicate vertical hauls, plotted as logarithms of the catches.

is similar to that of the estimation of bacterial numbers, the basic distribution of which, when the experimental technique is adequately controlled, has been shown by Fisher, Thornton \& MacKenzie (I922) to be Poisson. The value has therefore been calculated, for each pair of observations, of

$$
\chi^{2}=\frac{\left(n_{1}-n_{2}\right)^{2}}{\left(n_{1}+n_{2}\right)},
$$

where $n_{1}$ and $n_{2}$ are the numbers of each stage in a pair of duplicate hauls and when $\left(n_{1}+n_{2}\right)>$ IO. When $5<\left(n_{1}+n_{2}\right)<$ Io an adjusted value of $\chi^{2}$ has been used,

$$
\chi^{2}=\frac{\left(n_{1}-n_{2}\right)^{2}-2\left(n_{1}-n_{2}\right)+\mathrm{I}}{\left(n_{1}+n_{2}\right)} .
$$

Pairs in which $\left(n_{1}+n_{2}\right)<5$ have been neglected. 
If the basic distribution were truly Poisson this $\chi^{2}$ should, in a number of random samples, have a mean value of I and should be distributed in a known manner. For comparison with the data of Winsor \& Walford similar classes of $\chi^{2}$ have been selected and the distribution of this quantity is shown in Table I.

Table I. Distribution of Values of $\chi^{2}$ (I34 Pairs).

\begin{tabular}{|c|c|c|c|}
\hline$\chi^{2}$ & $\begin{array}{c}\text { Proportion } \\
\text { of values } \\
\text { expected } \\
\text { (Poisson) }\end{array}$ & $\begin{array}{c}\text { Number of } \\
\text { values } \\
\text { observed }\end{array}$ & $\begin{array}{c}\text { Proportion } \\
\text { of values } \\
\text { observed }\end{array}$ \\
\hline-0.016 & $O . I$ & 6 & 0.045 \\
\hline-0.064 & 0.1 & 6 & 0.045 \\
\hline-0.148 & 0.1 & 7 & 0.052 \\
\hline-0.275 & $O . I$ & 3 & 0.022 \\
\hline-0.455 & $O . I$ & 9 & 0.067 \\
\hline-0.708 & 0.1 & 8 & 0.059 \\
\hline$-\mathrm{I} \cdot 074$ & 0.1 & 9 & 0.067 \\
\hline 2 & 0.1 & I 2 & 0.089 \\
\hline-2 & 0.1 & I6 & 0.119 \\
\hline$-6 \cdot 635$ & 0.09 & 30 & 0.223 \\
\hline 6.63 & $0.0 \mathrm{I}$ & 28 & 0.209 \\
\hline
\end{tabular}

This distribution is far from theoretical for Poisson, and is similar to that obtained by Winsor \& Walford. The fact that there is an excess of large values of $\chi^{2}$ shows that there is an excess of samples showing relatively large differences between hauls.

Table II. Values of Total and Mean $\chi^{2}$ for varying Sample Size

\begin{tabular}{|c|c|c|c|}
\hline$\left(n_{1}+n_{2}\right)$ & $\begin{array}{l}\text { Number } \\
\text { of } \\
\text { samples }\end{array}$ & $S_{\chi^{2}}$ & $\bar{\chi}^{2}$ \\
\hline $\begin{array}{r}5-10 \\
-20\end{array}$ & $\begin{array}{r}18 \\
8\end{array}$ & $\begin{array}{l}44.57 \\
\text { I } 5.68\end{array}$ & $\begin{array}{l}2 \cdot 48 \\
\mathrm{I} \cdot 96\end{array}$ \\
\hline $\begin{array}{l}-20 \\
-40\end{array}$ & 24 & $\begin{array}{l}1500 \\
68.69\end{array}$ & $\begin{array}{l}1.90 \\
2.86\end{array}$ \\
\hline-60 & I8 & $43 \cdot 73$ & $2 \cdot 43$ \\
\hline-80 & IO & $21 \cdot 26$ & $2 \cdot 13$ \\
\hline-170 & I6 & $35 \cdot 53$ & 2.22 \\
\hline-400 & I9 & 69.08 & 3.64 \\
\hline-1000 & 9 & I6I.5I & $17 \cdot 83$ \\
\hline$>1000$ & I2 & I $726 \cdot$ I 5 & $\mathrm{I} 43.85$ \\
\hline
\end{tabular}

In Table II the mean values of $\chi^{2}$ have been tabulated by size groups and the results are again similar to those of Winsor \& Walford. Thus, the large hauls furnish a larger proportion than expected of the high values of $\chi^{2}$ as shown by the increase in the mean $\chi^{2}$ with increasing size of sample. It seems clear that other factors than the sampling variations of a random population are affecting the hauls. 
Assuming that the most important factor contributing to these variations is the volume of water filtered (or at least affecting the sample by its effect on the volume filtered) Winsor \& Walford derive the following expression for $\chi^{2}$ :

$$
\chi^{2}=\mathrm{I}+n \frac{\sigma_{v}^{2}}{\bar{v}^{2}}=\mathrm{I}+K^{2} \bar{n},
$$

where $\bar{n}=\frac{1}{2}\left(n_{1}+n_{2}\right), \sigma_{v}=$ standard deviation of volume, $\bar{v}=$ mean volume filtered.

There is little change in the value of $\chi^{2}$ up to $\left(n_{1}+n_{2}\right)=170$, with the present data, and beyond this point the size of these groups has to be greatly increased to obtain a reasonable number of samples. Grouping together gives Table III.

\section{TABLE III}

\begin{tabular}{|c|c|c|c|}
\hline$\left(n_{1}+n_{2}\right)$ & $\begin{array}{c}\text { Number of } \\
\text { samples }\end{array}$ & $S \chi^{2}$ & $\bar{\chi}^{2}$ \\
\hline $\begin{array}{r}0-170 \\
170-400\end{array}$ & $\begin{array}{l}94 \\
19\end{array}$ & $\begin{array}{r}229 \cdot 44 \\
69 \cdot 08\end{array}$ & $\begin{array}{l}2.44 \\
3.64\end{array}$ \\
\hline $400-1000$ & 9 & $16 \mathrm{I} \cdot 5 \mathrm{I}$ & 17.83 \\
\hline$>_{1000}$ & I 2 & I $726 \cdot \mathrm{I} 5$ & I 43.85 \\
\hline
\end{tabular}

These values are plotted in Fig. 2, and although the number of points is inadequate they can be considered as lying on a straight line passing through the point $\bar{\chi}^{2}=\mathrm{I}$, when $\bar{n}=0$. The equation of this line gives a value for the constant $K^{2}$ of 0.05 . The value suggested by Winsor \& Walford for $K^{2}$ is $0.04-0.06$ and they emphasize the fact that $K$ is not a universal constant. The agreement of the value calculated from the present data with their value is very satisfactory.

Since the coefficient of variation of a single observation is

$$
\frac{\sigma}{n}=\mathrm{IOO} /\left(\frac{\mathrm{I}}{n}+K^{2}\right),
$$

then putting $K^{2}=0.05$, and for a total catch of $100(n=100)$,

$$
\frac{\sigma}{n}=25 \% \text {. }
$$

The above agreement appears to suggest that the basic assumption, namely a random distribution of the population, holds for the present series, and that the variations between the hauls are largely due to differences in the volumes of water filtered. It follows that since different stages of a number of species were counted, all are randomly distributed, that is, there is no association between any of the animals or their various stages. This does not mean that changes in density do not take place in a vertical direction but only that at any point in the vertical section there is a random distribution of the species and their separate stages.

An alternative method of analysing the results of such replicate hauls is possible and has been employed by Winsor \& Clarke (I940). Both new data 
and that previously considered by Winsor \& Walford were used, and submitted to an analysis of variance; this technique will now be applied to the present data.

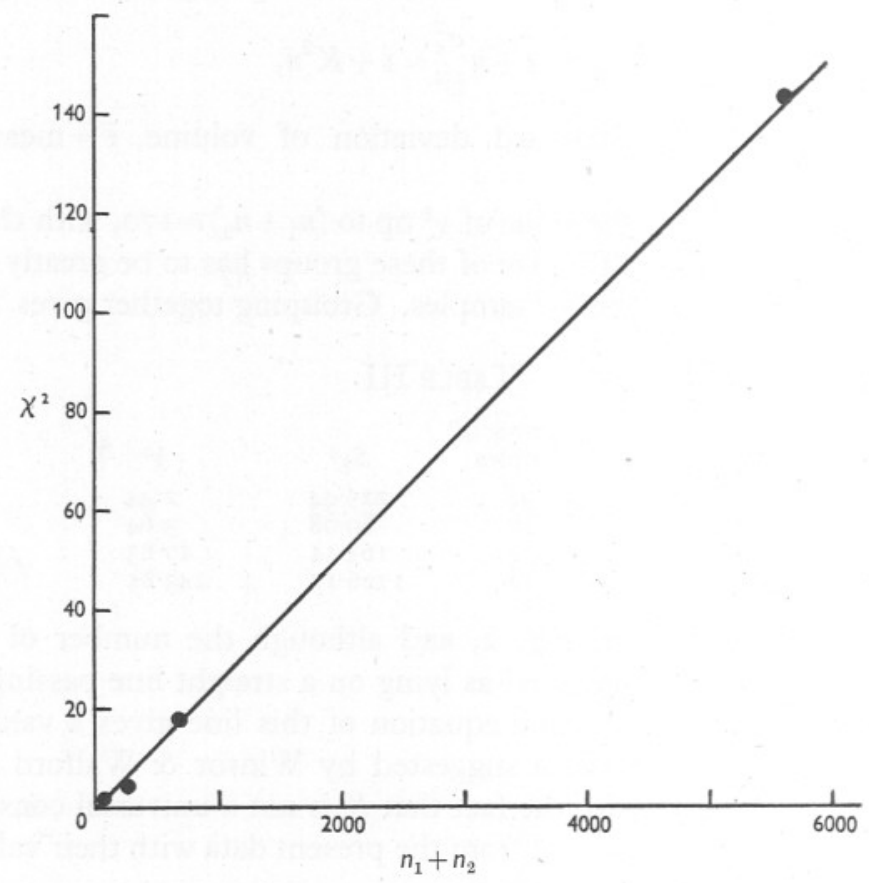

Fig. 2. The relationship between the mean value of $\chi^{2}$ (grouped values) and the mean catch in paired hauls.

Four of the above six undivided hauls, which have been treated as three pairs, were taken consecutively and these four will be analysed. For the four replicate hauls with eight separate stages of each of the four species counted there are in all $\mathrm{I} 28$ observations. (Six results have been neglected because of small numbers.) The results of the analysis can be conveniently tabulated as follows. (Logarithmic values of the catches are used throughout; for details of the theory underlying the method, the paper by Winsor \& Clarke (I940) should be consulted.)

The analysis of variance gives the following:

$\begin{array}{ccrc}\begin{array}{c}\text { Source of } \\ \text { variation } \\ \text { Main effects: }\end{array} & \begin{array}{c}\text { Degrees of } \\ \text { freedom }\end{array} & \begin{array}{c}\text { Sum of } \\ \text { squares }\end{array} & \begin{array}{c}\text { Mean } \\ \text { square }\end{array} \\ \text { Hauls (H) } & 3 & 0.2255 & 0.0752 \\ \text { Stages (S) } & 3 \mathrm{I} & 57.3872 & \mathrm{I} \cdot 85 \mathrm{I} 2 \\ \begin{array}{c}\text { Interaction: } \\ \text { H } \times \text { S }\end{array} & 93 & \mathrm{I} \cdot 225 \mathrm{I} & 0.0132 \\ \text { Totals } & \mathrm{I} 27 & 58.8378 & -\end{array}$


The various estimates obtained from the mean squares can be conveniently summarized thus:

(i) The mean square for the interaction is an estimate of $\sigma_{\mathrm{SH}}^{2}$, the "within haul' variance. Hence $\sigma_{\mathrm{SH}}^{2}=0.0 \mathrm{I}_{3} 2$, standard deviation $=\sigma_{\mathrm{SH}}=0 . \mathrm{II} 49$, and $\log \mathrm{I} \cdot 303=0 \cdot \mathrm{II} 49$, corresponding to a coefficient of variation of $30.3 \%$.

(ii) $\sigma_{\mathrm{H}}^{2}$ is the 'haul to haul' variance. The mean square for the hauls is an estimate of $32 \sigma_{\mathrm{H}}^{2}+\sigma_{\mathrm{SH}}^{2}=0.0752$. Hence $\sigma_{\mathrm{H}}^{2}=0.0019$, standard deviation $=\sigma_{\mathrm{H}}=0.0440$, and $\log \mathrm{I} \cdot \mathrm{I070}=0.0440$, corresponding to a coefficient of variation of $10.7 \%$.

(iii) The variance of a single observation is $\sigma_{\mathrm{H}}^{2}+\sigma_{\mathrm{SH}}^{2}=0.015 \mathrm{I}$, standard deviation $=\sqrt{ }\left(\sigma_{\mathrm{H}}^{2}+\sigma_{\mathrm{SH}}^{2}\right)=0 \cdot 1228$, and $\log \mathrm{I} \cdot 326=0 \cdot 1228$, corresponding to a coefficient of variation of $32 \cdot 6 \%$.

Winsor \& Clarke's results indicated a coefficient of variation of $53 \%$ for vertical hauls, and $3 \mathrm{I} \%$ for oblique hauls ( $n$ is large), and they suggest that the greater accuracy for oblique hauls is worth further consideration. However, the data now presented show an accuracy for replicate vertical hauls comparable with these authors' value for oblique hauls. It would appear that the greater accuracy of the present series may be ascribed to the more favourable working conditions, viz. a sheltered sea loch in contrast to the less favourable open sea conditions under which Winsor \& Clarke's material was collected.

\section{The Divided Hauls}

Throughout the season's work four undivided hauls (bottom to surface) and one divided (bottom to Io m., Io $\mathrm{m}$. to surface) haul were taken consecutively, the four undivided hauls being pooled and an aliquot part counted.

A preliminary inspection of the data indicated that as a first approximation the results could be divided into two classes with regard to the discrepancy between the divided and undivided hauls, depending upon whether the animals were mainly above or mainly below the point at which the hauls were broken. The results for those hauls in which the organisms were below the Io $\mathrm{m}$. level will be considered first.

\section{Animals all below the depth at which the haul was divided.}

Since the divided haul is suspect, it is first necessary to examine the assumption that it gives a reliable qualitative estimate of the distribution in relation to the $10 \mathrm{~m}$. level. An inspection of the results indicated that when the organisms were above the Io $\mathrm{m}$. level the mean total catch of both divided and undivided hauls tended to be similar and under these circumstances, as shown later, they were not significantly different (p. 440). This indicates that no loss is incurred in the ro-0 m. haul. If nothing is caught in the upper Io $\mathrm{m}$. by the second part of the divided haul it can therefore be assumed that the qualitative information, namely that the animals are all below the ro m. level, is substantially correct. 
The data for Microcalanus pygmaeus, no stages of which (except the nauplii) were ever found in significant numbers above the ro $\mathrm{m}$. level, will first be considered. There were ten different days throughout the season when divided and undivided hauls were taken, and since seven stages were counted there are I40 observations. The results are plotted in Fig. 3 and suggest a loss in the divided haul (compare Fig. I).

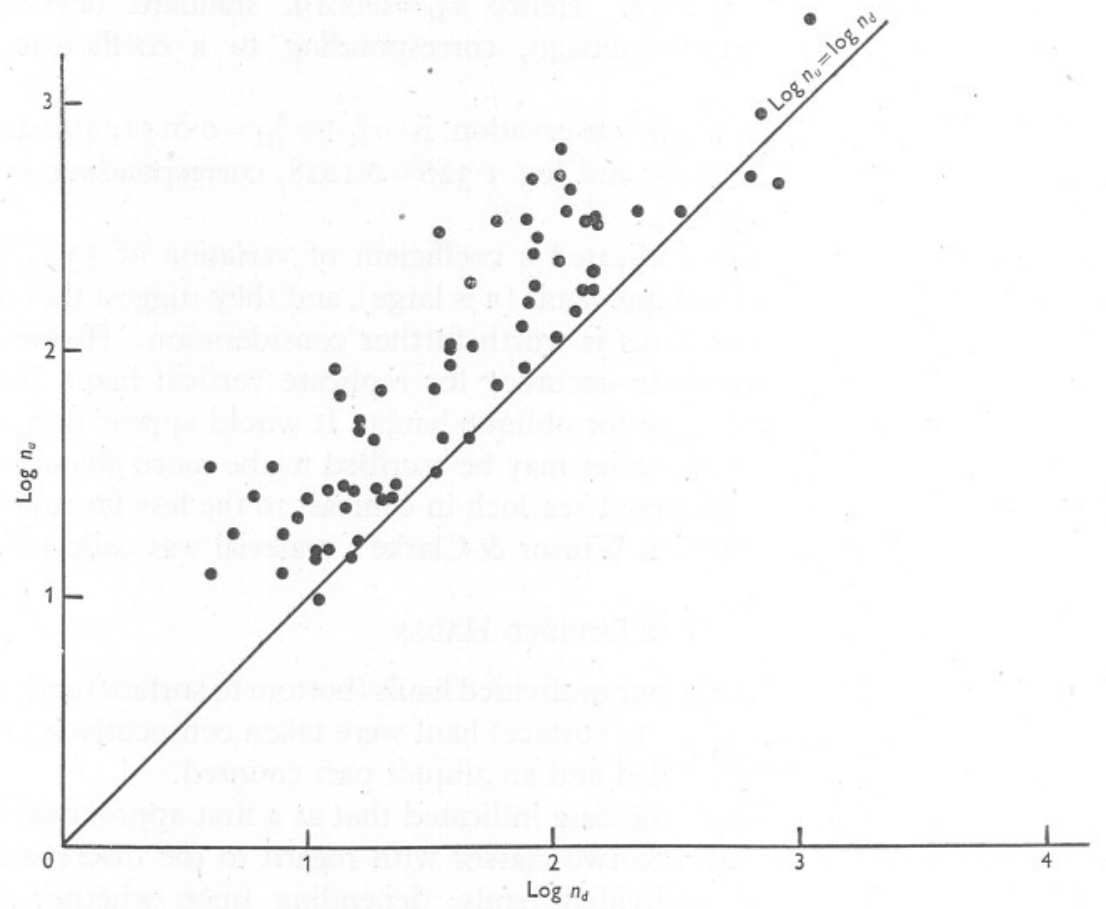

Fig. 3. The relationship (in Microcalanus pygmaeus) between catches (log values) for all stages in divided and undivided hauls taken over a season's work when all stages are below point of division of the haul.

The analysis of variance gives the following:

$\begin{array}{lccc}\begin{array}{l}\text { Source of } \\ \text { variation }\end{array} & \begin{array}{c}\text { Degrees of } \\ \text { freedom }\end{array} & \begin{array}{c}\text { Sum of } \\ \text { squares }\end{array} & \begin{array}{c}\text { Mean } \\ \text { square }\end{array} \\ \begin{array}{l}\text { Main effects: } \\ \text { Stages (S) }\end{array} & 6 & 20.4588 & 3.4098 \\ \text { Day (D) } & 9 & 15.6570 & 1.7400 \\ \text { Haul (H) } & \text { I } & 4.4500 & 4.4500 \\ \begin{array}{l}\text { First-order interactions: } \\ \text { S } \times \text { D }\end{array} & 54 & 10.0994 & 0.1870 \\ \text { S } \times \text { H } & 6 & 0.3210 & 0.0535 \\ \text { D } \times \text { H } & 9 & 0.9230 & 0.1020 \\ \text { Second-order nteraction : } & & \\ \text { S } \times \text { D } \times \text { H } & 56 & 0.8875 & 0.0164 \\ \text { Totals } & \text { I39 } & 52.5078 & -\end{array}$


It is difficult to assign the day-haul and stage-haul interaction to other than accidental variations, and the values obtained will therefore be added to the second-order interaction to give a residual mean square of 0.0300 . The mean square for the hauls can be tested for significance against this value by the $z$ test:

$$
\begin{aligned}
z & =\frac{1}{2}\left(\log _{e} 4.4500-\log _{e} 0.0300\right) \quad n_{1}=\mathrm{I}, n_{2}=7 \mathrm{I}, \\
& =2 . \mathrm{I} 5 .
\end{aligned}
$$

Since the $5 \%$ point for $z, n_{1}=\mathrm{I}, n_{2}=\infty$ is 0.6729 , the difference between the hauls is significant and the loss in the divided haul indicated by Fig. 3 is significant. It should be pointed out that this is true even though replicate undivided hauls showed a significant difference, since a set of hauls is here under consideration. An alternative treatment, which gives the same result, is to consider the divided and undivided hauls on each date separately. Associating with the undivided hauls the standard error $\sigma=\sqrt{ }\left(\sigma_{\mathrm{H}}^{2}+\sigma_{\mathrm{SH}}^{2}\right)(\mathrm{p} .435)$ allows for the significant difference between the hauls found previously. Assuming that the divided haul has the same standard error, then the standard error of the difference $n_{u}-n_{d}$ is $\sqrt{ }(2 \sigma)$ and the usual test for significance can be applied.

It is desirable to consider possible reasons for the loss in the divided haul. From the bottom to the ro $\mathrm{m}$. level the divided and undivided hauls are identical, and since in the hauls under consideration no animals are present above Io m., it is impossible to escape from the conviction that loss of animals must take place when the net is closed at the ro $\mathrm{m}$. level in the divided hauls. Two possible causes for this loss may be suggested:

(i) Any organisms still above the throttling gear in the upper part of the net when it is closed will automatically be lost.

(ii) If water is forced upwards from the bottom part of the net when it is closed a further loss of the catch may take place. Three possible mechanisms for such a passage of water upwards may be suggested:

(a) Probably the most important factor is the amount of slack in the throttling cord of the closing mechanism so that when the hauling line is released the net must slow down.

(b) Any deceleration in hauling speed immediately prior to closing the net will, if the net has been moving at a constant speed, tend to force water upwards carrying organisms with it. The person working the winch usually knows when the net is approaching the Io m. point and may, without realizing it, tend to slow down.

(c) The sudden closing of the net may tend to force a small quantity of water out of the net rather than force it through the meshes.

If in a series of hauls the catch were largely obtained at the same or similar levels then, as a first approximation, all the catch would be expected to be similarly distributed throughout the net and bucket at the time of throttling. Since the loss of water due to the factors outlined above might also be expected 
to be similar in a comparable series of hauls, the loss under these circumstances would be proportional to the total catch.

This relationship can be expressed in the form of the regression line of divided and undivided hauls (divided haul being considered as the dependent variable), but since it will be shown that the stages react differently during the season any such relation can only have an average value. The regression line is given by

$$
\log n_{d}=0.84 \log n_{u}-0.03 \text {, }
$$

where $n_{d}$ and $n_{u}$ are the numbers in the divided and undivided hauls, respectively. This would mean that for a catch of $\mathrm{IO0}\left(n_{u}\right), 50 \%$ of the animals would be lost in the divided haul.

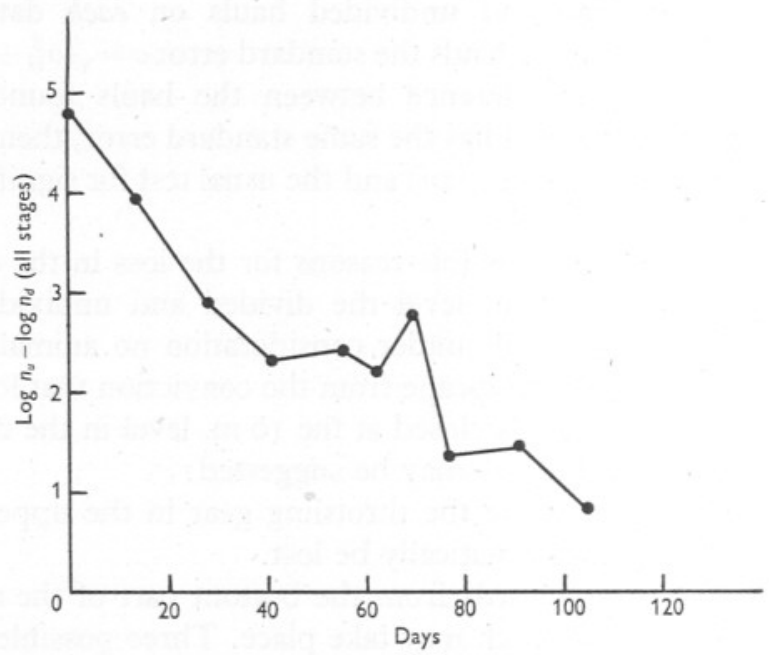

Fig. 4. The ratio of the divided and undivided hauls $\left(\log n_{u}-\log n_{d}\right)$ for total catch, i.e. all stages, plotted against date of catch, showing change in ratio with time.

If the ratio of the catches in the two hauls is plotted against the date of the haul, the figures suggest that the loss changes (in general decreases) throughout the season (Fig. 4).

This is substantiated by analysing the values for the ratio $\left(\log n_{u}-\log n_{d}\right)$ in relation to the date; the analysis of variance gives the following:

$\begin{array}{cccc}\begin{array}{c}\text { Source of } \\ \text { variation }\end{array} & \begin{array}{c}\text { Degrees of } \\ \text { freedom }\end{array} & \begin{array}{c}\text { Sum of } \\ \text { squares }\end{array} & \begin{array}{c}\text { Mean } \\ \text { square }\end{array} \\ \begin{array}{c}\text { Main effects: } \\ \text { Days (D) }\end{array} & 9 & \begin{array}{l}1.7625 \\ 0.0623\end{array} & \begin{array}{c}0.1958 \\ 0.0104\end{array} \\ \begin{array}{c}\text { Stages (S) } \\ \text { Interaction: }\end{array} & 6 & & \\ \mathrm{D} \times \mathrm{S} & 54 & 1.5008 & 0.0278 \\ \quad \text { Totals } & 69 & 3.3256 & -\end{array}$


The value of the mean square for days is significant, so that the difference between the catches varies significantly with the day on which the catch was taken. The difference does not vary according to the particular stage under consideration. The following is suggested as an explanation of this result. The relation between catch and loss might be expected to depend to some extent on the position in the hauls at which the catch was largely made. If the animals were caught in the same vertical range then the same amount of consolidation (if any) into the receiving vessel and the same distribution throughout the various parts of the net might be expected when the net is closed, so that under similar conditions of water loss on closure, a proportional amount of organisms would be expected to be lost. However, if on certain occasions some of the animals were caught in the deeper layers, they might be expected to be somewhat differently distributed throughout the net and receiving vessel, in general being carried farther down into the lower parts of the net during the later part of the haul. The loss on closure might then be reduced. This explanation would imply vertical migrations of the various stages during the season which is in accord with general observations. If this is true then it indicates that the stages of $M$. pygmaeus, although always below the Io $\mathrm{m}$. level, do migrate vertically throughout the season. Since the discrepancy between the divided and undivided hauls is less towards the end of the season (see Fig. 4, where $\log n_{u}-\log n_{d}$ approaches o later in the season), the foregoing agreement would imply a migration to the deeper level during the latter part of the year; such an implication is in agreement with the facts already ascertained for other copepods from such data on their behaviour as are available. It should be possible to relate these changes to the factors which control seasonal vertical migration, but the available information is inadequate. An inspection of the data in relation to temperature which might be expected to affect such migration gives no significant correlation. However, changes in the order of the discrepancy were most marked when there were sudden changes in temperature.

It should be pointed out that this change in the relationship between the divided and undivided haul throughout the season could conceivably be explained by some gradual change in technique; this explanation is hardly adequate.

This loss of catch with vertical divided hauls does not appear to be peculiar to the present series of observations. Thus Kemp, Hardy \& Mackintosh (I929) and also Marr (1938) draw attention to the discrepancy between 'open' and 'closed' horizontal hauls using the same net, the 'closed' haul always yielding a comparatively poor catch. They suggest that the 'open' horizontal haul possibly gives a fictitious result owing to catching animals whilst hauling in the net. The loss of catch in the 'closed' haul as a result of the tendency of the net to fall backwards could have contributed materially to the discrepancy, since it would lead to losses in the 'closed' haul. 
Wiborg (I948) has recently published a detailed account of a comparison of several methods of taking vertical and oblique hauls and an inspection of his Table IV indicates a loss with the vertical closing net. Some of his results are grouped together and shown in summary form in Table IV. The figures for the Clarke-Bumpus sampler (P.S.-8) are organisms per I000 1., while those for the closing net $(8 / 72)$ are the total catch. If the net is behaving in a similar manner throughout each haul it would be expected that the ratio of the

\section{TABLE IV}

\begin{tabular}{|c|c|c|c|c|c|c|c|c|}
\hline \multirow[b]{2}{*}{ Calanus finmarchicus: } & \multicolumn{2}{|c|}{$25-0$} & \multicolumn{2}{|c|}{$50-25$} & \multicolumn{2}{|c|}{$100-50$} & \multicolumn{2}{|c|}{ I50-100 } \\
\hline & P.S. -8 & $8 / 72$ & P.S. -8 & $8 / 72$ & P.S. -8 & $8 / 72$ & P.S. -8 & $8 / 72$ \\
\hline $\begin{array}{l}\text { Copepodites and adults } \\
\text { Nauplii and eggs }\end{array}$ & $\begin{array}{l}4188 \\
4303\end{array}$ & $\begin{array}{r}21183 \\
6900\end{array}$ & $\begin{array}{r}306 \\
4769\end{array}$ & $\begin{array}{l}2216 \\
4609\end{array}$ & $\begin{array}{l}\text { II } 7 \\
2 \text { I } 4\end{array}$ & $\begin{array}{r}\text { I94 } \\
60\end{array}$ & $\begin{array}{r}46 \\
122\end{array}$ & $\begin{array}{r}138 \\
25\end{array}$ \\
\hline Calanus hyperboreus: & & & & & & & & \\
\hline $\begin{array}{l}\text { Copepodites and adults } \\
\text { Nauplii and eggs }\end{array}$ & $\begin{array}{r}\text { IO9 } \\
94\end{array}$ & $\begin{array}{l}422 \\
500\end{array}$ & $\begin{array}{l}54 \\
53\end{array}$ & $\frac{76}{-}$ & 26 & $\underline{I 4}$ & $\stackrel{I}{-}$ & $5 \mathrm{I}$ \\
\hline Other organisms than copepods & 598 & I942 & 833 & 338 & I86 & I 78 & 23 & 58 \\
\hline
\end{tabular}

Clarke-Bumpus sampler catch to the net catch would be approximately constant, an assumption which is independent of the absolute filtration coefficient of the net. Although the species and stages do not behave in an identical way it is clear from the figures that the ratio (sampler/net) is usually much lower in the $0-25 \mathrm{~m}$. haul than the deeper hauls. Since it may be presumed that the o-25 m. hauls were made without closing the net it would appear that the lower ratio for this section of the haul is due to not closing the net and that the catches in the other divided net hauls are lower as a result of losses on closing the net.

Hauls in which all the organisms were above $10 \mathrm{~m}$.

Since it has been shown that in general, in the divided haul, there is a loss of organisms caught below Io $\mathrm{m}$. it is again necessary to examine the possibility that the qualitative division is correct. In the hauls under consideration no animals were caught below Io $\mathrm{m}$. in the divided haul; a small number may have been lost but these may be neglected if there are moderate numbers above Io $\mathrm{m}$. Both the divided and undivided hauls can, therefore, be considered as catching animals only between Io $\mathrm{m}$. and the surface.

The results for Centropages hamatus have been used, since on three occasions six of the stages were all above the $10 \mathrm{~m}$. level on three different days during the season. The analysis of variance gives the results as shown on p. 44I.

The day-haul and haul-stage can again be combined with the second-order interaction to give a residual mean square of 0.074 .

The difference between the hauls is not significant so that the divided and undivided hauls do not differ significantly when all the organisms are caught above the ro $\mathrm{m}$. level in the two hauls. 
The coefficient of variation of a single observation can be obtained from the residual variance which is an estimate of

$$
\sigma_{\mathrm{R}}^{2}=0.074 \text {. }
$$

Hence the standard deviation $=0.272, \log \mathrm{I} \cdot 87 \mathrm{I}=0.272$, corresponding to a coefficient of variation of $87 \%$.

\begin{tabular}{|c|c|c|c|}
\hline \multirow{2}{*}{$\begin{array}{l}\text { Source of } \\
\text { variation }\end{array}$} & \multicolumn{2}{|c|}{ Analysis of variance } & \multirow[b]{2}{*}{$\begin{array}{l}\text { Mean } \\
\text { square }\end{array}$} \\
\hline & $\begin{array}{l}\text { Degrees of } \\
\text { freedom }\end{array}$ & $\begin{array}{l}\text { Sum of } \\
\text { squares }\end{array}$ & \\
\hline \multicolumn{4}{|l|}{ Main effects: } \\
\hline Days (D) & 2 & 0.701 & $0.35 \mathrm{I}$ \\
\hline Hauls (H) & I & 0.063 & 0.063 \\
\hline Stages (S) & 5 & $\mathrm{I} \cdot 22 \mathrm{I}$ & 0.244 \\
\hline \multicolumn{4}{|c|}{ First-order interactions: } \\
\hline $\mathrm{D} \times \mathrm{H}$ & 2 & 0.116 & 0.058 \\
\hline & 5 & & $0.14 \mathrm{I}$ \\
\hline $\mathrm{H} \times \mathrm{S}$ & I0 & I. 784 & 0.178 \\
\hline \multicolumn{4}{|c|}{ Second-order interaction: } \\
\hline $\mathrm{D} \times \mathrm{H} \times \mathrm{S}$ & Io & $0.43 \mathrm{I}$ & 0.043 \\
\hline Totals & 35 & 5.019 & \\
\hline
\end{tabular}

It is evident that the estimate of the population of these short Io $\mathrm{m}$. hauls is very much less accurate than that obtained in the long hauls previously discussed.

Several sources of error in these short hauls may be suggested. Any error in measurement of the $\mathrm{Io} \mathrm{m}$. depth either by inaccurate adjustment of the metre wheel, or any subsequent slip in the friction drive, whilst having little effect when the animals are being caught in a o-60 m. haul, would considerably affect the catch when it is being taken through a Io m. haul, taking only $20 \mathrm{sec}$; an error of $\pm \mathrm{I} \cdot 0 \mathrm{~m}$. would affect the volume sampled by $\pm 10 \%$. Further, the net may not begin to fish efficiently immediately winding commences; the winder may, in releasing the winch catch, drop the net a small distance, and constant speed may not be attained for some seconds.

\section{Hauls with animals above and below ro $\mathrm{m}$.}

These are subject to all the errors discussed above, and the resultant effect will be determined by the proportions of the population above and below the level at which the haul is broken. If the animals are largely above this level the estimate of the population will be a poor one with no significant difference between divided and undivided. As the animals are found in greater proportion below the dividing level the error due to losses on closing the net will become more important. It is possible to apply an overall correction factor to the lower section of the haul, but in view of the change of reaction with time of the various stages it can hardly be considered satisfactory. Further analysis of the data does not appear, therefore, to be profitable, but the above may be illustrated by plotting the ratio between the undivided and the divided hauls $\left(\log n_{u}-\log n_{d}\right)$ against the percentage in the upper $10 \mathrm{~m}$. of the haul. The 
results for the first part of the season's hauls on C. hamatus are shown in Fig. 5. If the hauls were identical the points would lie on the line $\log n_{u}-\log n_{d}=0$, but the loss ( $\log n_{u}-\log n_{d}$ positive) increases as the population of the animals below the ro $\mathrm{m}$. level increases.

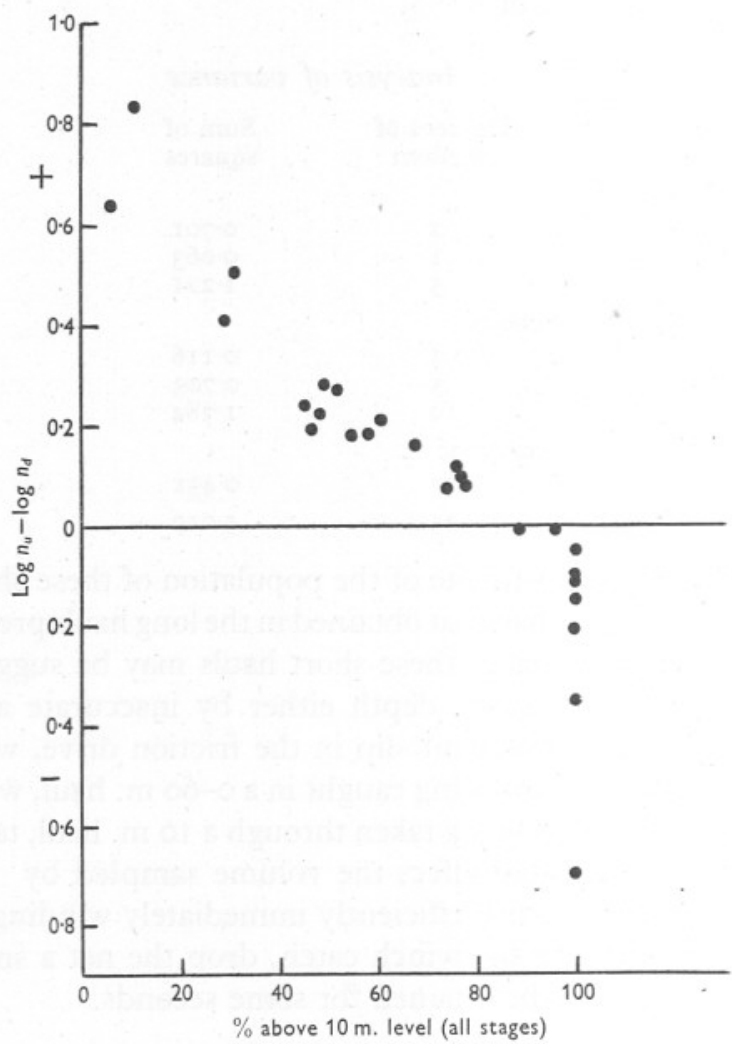

Fig. 5. Change in ratio of divided and undivided hauls (in Centropages hamatus) as the population is found in greater proportion below the point of division of the haul.

\section{The Experimental Data}

It has been indicated that there are losses in a divided haul when the net is closed by a throttling cord, and it has been suggested that this is largely due to deceleration with a consequent loss of water from the net and that this water carries organisms with it. The sequence of events on throttling can be illustrated by reference to the Discovery net whose dimensions are given in full detail by Kemp et al. (1929).

The net has $3 \mathrm{ft}$. bridles on a $50 \mathrm{~cm}$. diameter mouth and between the mouth and the filtering surface is a canvas cylinder whose depth to the closing rings is 23 in., i.e. a total length of 57 in. from the release gear to the throttling band. 
The total length of the throttling cord doubled is $16 \frac{1}{2} \mathrm{ft}$. The drop on closing, if the net were stationary, would be the difference between 57 in. and 99 in.say $3 \frac{1}{2} \mathrm{ft}$. Of this drop about $\mathrm{I} \mathrm{ft}$. takes place before closing starts and a further $2 \frac{1}{2} \mathrm{ft}$. during closing. It should be emphasized that some slack is necessary in the throttling cord for normal working of the closing mechanism, particularly under adverse conditions, but if the throttling line were tight between the attachment to the release and throttling loops, there would be negligible fall before the closing started and the half of the circumference of the circle, $3 \mathrm{I}$ in., as the rope tightened.

In the case of a net which is being hauled vertically there will be a tendency for it to continue to move upwards after being released from the hauling line owing to its own momentum, and the resultant movement of the net will

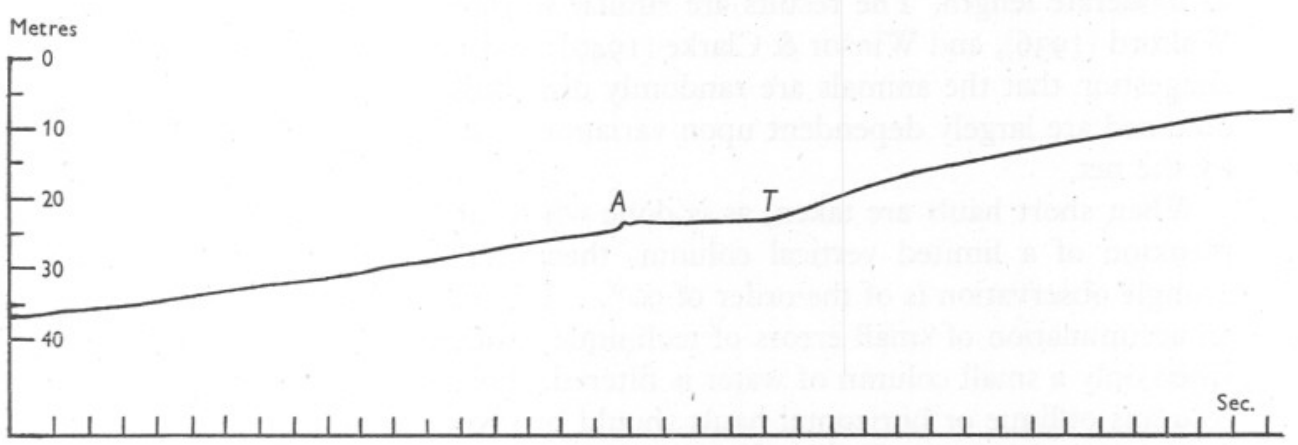

Fig. 6. Copy of the tracing of a depth record; constant speed to $A$, at which point messenger engaged, the weight coming on to throttling line at $T$. Horizontal scale in seconds; vertical scale in metres with an arbitrary zero.

depend upon the speed of hauling and the weight attached to the net. If the net remained stationary after release of the hauling rope, then at a hauling speed of $0.5 \mathrm{~m}$. $/ \mathrm{sec}$. it would be approximately $2 \mathrm{sec}$. before the weight came on the throttling line again. A record of the changes in position of a net on closing was obtained by attaching a small depth recorder to the bucket of the net. The net was handled by a mechanical winch in order to obtain a uniform hauling speed and the conditions were chosen so that there was as little movement of the ship as possible. Further, in order to exaggerate the effect about I ft. extra throttling rope was used. Fig. 6 is copied from a photograph of the record. No actual fall of the net is shown but after the messenger engages (at $A$ ), the net remains virtually at the same level until caught up again (at $T$ ) by the throttling rope.

That the slowing down of the net causes water to be ejected from the net was confirmed by taking a film using a model net. ${ }^{1}$ The net was a scale model, one-

\footnotetext{
1 This and a number of other films were taken by Mr F. M. Marshall, and his expert assistance is gratefully acknowledged.
} 
fifth of the Discovery net, without the canvas top. In view of the difficulties of working vertically, a horizontal tow was made, using an electric motor to obtain uniform speed. Inside the opening of the net was fastened a coarse mesh bag containing finely powdered potassium permanganate. The effect of closing the net was imitated by stopping the motor and reducing the forward speed by a line attached to the tail of the net. Part of the film is shown in Pl. I. The film was taken at a speed of 64 frames/sec., and the ejection of water when the net is stopped can be clearly seen.

\section{Discussion AND SUMMARY}

The analysis of data on replicate vertical plankton hauls gives a value of the order of $35 \%$ for the coefficient of variation of a single observation for a haul of moderate length. The results are similar to those presented by Winsor \& Walford (I936), and Winsor \& Clarke (I940); and are not at variance with the suggestion that the animals are randomly distributed, and that the variations obtained are largely dependent upon variation in the volume of water filtered by the net.

When short hauls are taken, as is done when information is sought on the plankton of a limited vertical column, then the coefficient of variation of a single observation is of the order of $90 \%$. It is suggested that this is due to an accumulation of small errors of technique which weight the result heavily when only a small column of water is filtered. For examination of such short columns oblique or horizontal hauls should be given consideration.

It is shown that in divided hauls in which the net is closed on the Nansen principle losses in catch take place and it would be advisable to abandon its use in quantitative plankton work. The alternative seems to be an apparatus such as the Clarke-Bumpus sampler (Clarke \& Bumpus, I940), or a Kofoidtype net for horizontal hauls (Kofoid, I9I2).

Any mechanism which, as a result of its closing action, results in a tendency for the net to fall will cause a loss in the catch, although the presence of a cone and a small opening would tend to reduce this loss (Kofoid, I9II).

\section{REFERENCES}

Baldi, E., Cavalli, L. L. \& Pirocchi, L., I945. Condizioni della distribuzione del mesoplancton nel pelago di un grande lago oligotrofo (Lago Maggiore). Mems. Istituto Ital. Idrobiol. Milano, Vol. 2, pp. 253-90.

Clarke, G. L. \& Bumpus, D. F., I940. The plankton sampler-an instrument for quantitative plankton investigations. Limnological Soc. Amer. Spec. Publ., No. 5.

Fisher, R. A., Thornton, H. G. \& MAcKenzie, W. A., I922. The accuracy of the plating method of estimating the density of bacterial populations. Ann. Appl. Biol., Vol. 9, p. 323.

GARDINER, A. C., I93I. The validity of single vertical hauls of the international net in the study of the distribution of plankton. Fourn. Mar. Biol. Assoc., Vol. I7, pp. $449-72$. 
Hensen, V., I887. Úber die Bestimmung des Plankton. 5. Ber. Komm. Wiss. Unters. Deut. Meer, pp. I2-I6.

- I900-I2. Ueber die quantitative Bestimmung der kleineren Planktonorganismen und über den Diagonal-Zug mittelst geeigneter Netzformen. Wiss. Meersunt., Bd. 5, pp. 69-81.

Herdman, W. A., I92I. Variations in successive vertical plankton hauls at Port Erin. Proc. and Trans. L'pool Biol. Soc., Vol. 35, pp. I6I-74.

Kemp, S., Hardy, A. C. \& Mackintosh, N. A. I929. 'Discovery' Investigations. Objects, Equipment and Methods. Discovery Reports, Vol. I, pp. I4I-232.

Koford, C. A., I9II. On a self-closing plankton net for horizontal towing. Univ. Calif. Publ. Zool., Vol. 8, No. 8, pp. 3II-48.

- 19I2. A new horizontal self-closing plankton net. Intern. Rev. ges. Hydrobiol. ydrogr., Bd. 5, pp. 9I-2.

KüNNE, Cl., I929. Vergleich der Fangfähigkeit verschiedener Modelle von PlanktonNetzen. Rapp. Proc.-Verb. Cons. Int. Explor. Mer, Vol. 59, pp. I-24.

— 1933. Weitere Untersuchungen zum Vergleich der Fangfähigkeit verschiedener Modelle von vertikal fischenden Plankton-Netzen. Rapp. Proc.-Verb. Cons. Int. Explor. Mer, Vol. 83, pp. I-36.

LohmanN, H., I903. Neue Untersuchungen über den Reichthum des Meeres an Plankton und über die Brauchbarkeit der verschiedenen Fangmethoden. Wiss. Meersunt., Kiel, Bd. 7, pp. I-86.

MARR, J. W. S., I938. On the operation of large plankton nets. Discovery Reports, Vol. I8, pp. 105-20.

Marshall, S. M., I949. On the biology of small copepods in Loch Striven. Fourn. Mar. Biol. Assoc., Vol. 28, pp. 45-I22.

Marshall, S. M., Nicholls, A. G. \& OrR, A. P., I934. On the biology of Calanus finmarchicus. V. Seasonal distribution, size, weight and chemical composition in Loch Striven in 1933, and their relation to phyto-plankton. Fourn. Mar. Biol. Assoc., Vol. 19, pp. 793-819.

Nansen, F., I915. Closing-nets for vertical hauls and for horizontal towing. Publ. de Circonstance, No. 67.

Silliman, R. P., I946. A study of variability in plankton townet catches of Pacific pilchard Sardinops caerulea eggs. Fourn. Mar. Res., Vol. 6, No. I, pp. 74-83.

WIBORG, K. F., I948. Experiments with the Clarke-Bumpus Plankton Sampler and with a plankton pump in the Lofoten area in northern Norway. Rep. on Norwegian Fish. and Marine Investigations, Vol. 9, No. 2.

Winsor, C. P. \& ClaRke, G. L. I940. A statistical study of variation in the catch of plankton nets. Fourn. Mar. Res., Vol. 3, pp. I-34.

WINSOR, C. P. \& WALFORD, L. A., I936. Sampling variations in the use of plankton nets. Fourn. Cons. Int. Explor. Mer, Vol. II, pp. I90-204. 


\section{EXPLANATION OF PLATES}

\section{PLATE I}

Photograph of escape of material from net on stopping (consecutive frames from top left to bottom right). The film was taken at 64 frames/sec. and the speed of towing was approximately $0.5 \mathrm{~m}$. $/ \mathrm{sec}$. Hauling was stopped at the $3 \mathrm{rd}$ frame (A).

\section{PLATE II}

Another photographic record of material escaping from the net (consecutive frames from top left to bottom right). Hauling was stopped at the 3 rd frame (A). 
Journ. Mar. BIol. Assoc. XXVIII (2)
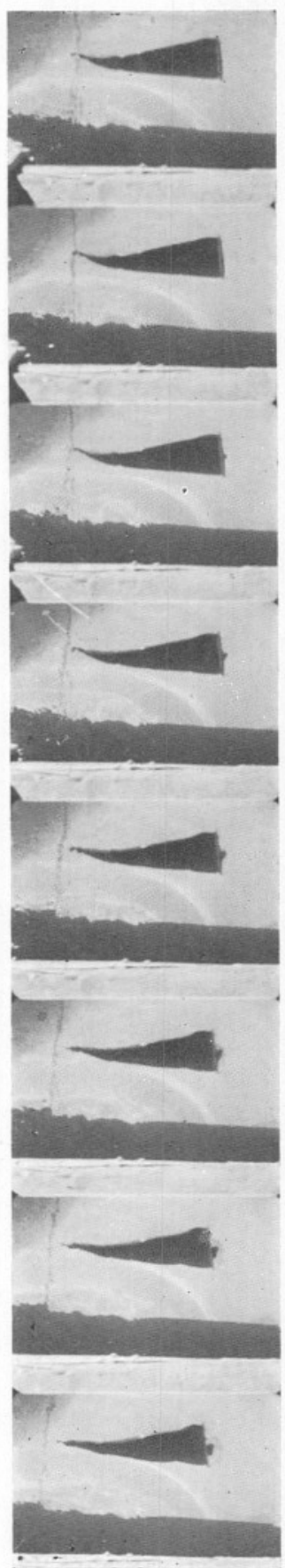

BARNES. PLATE I

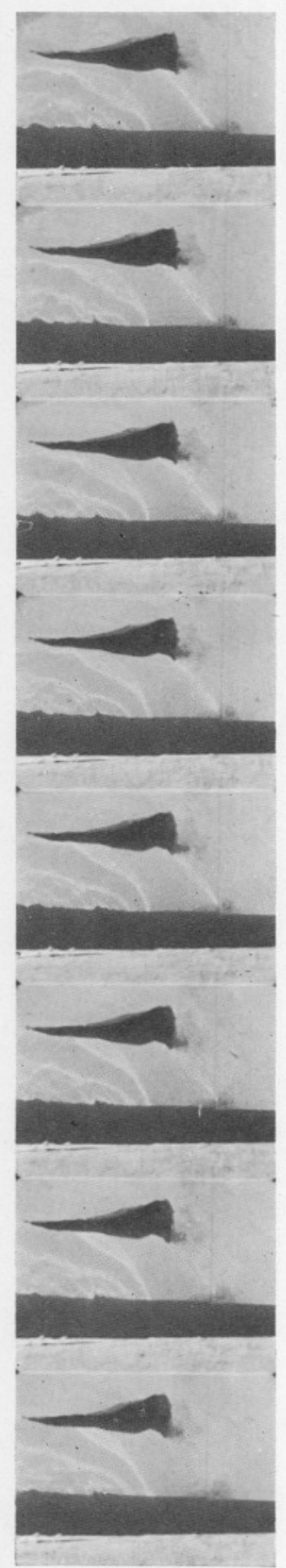




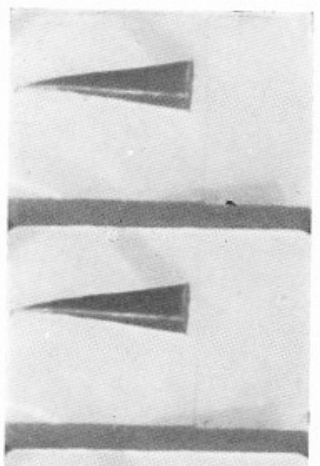

A
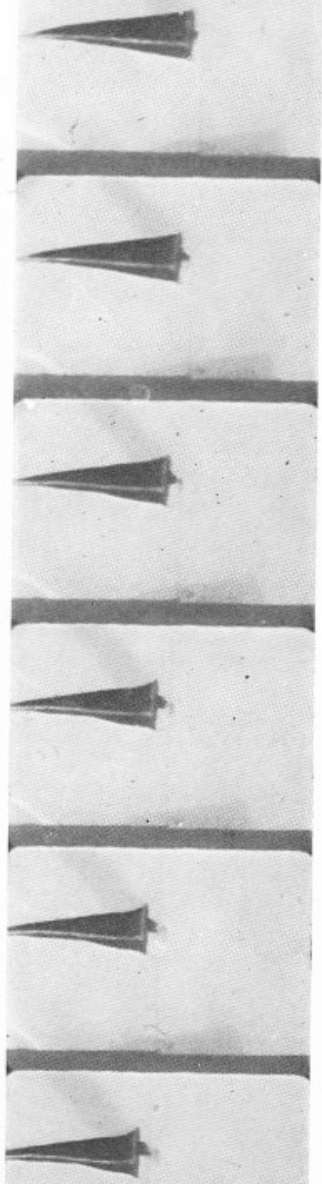
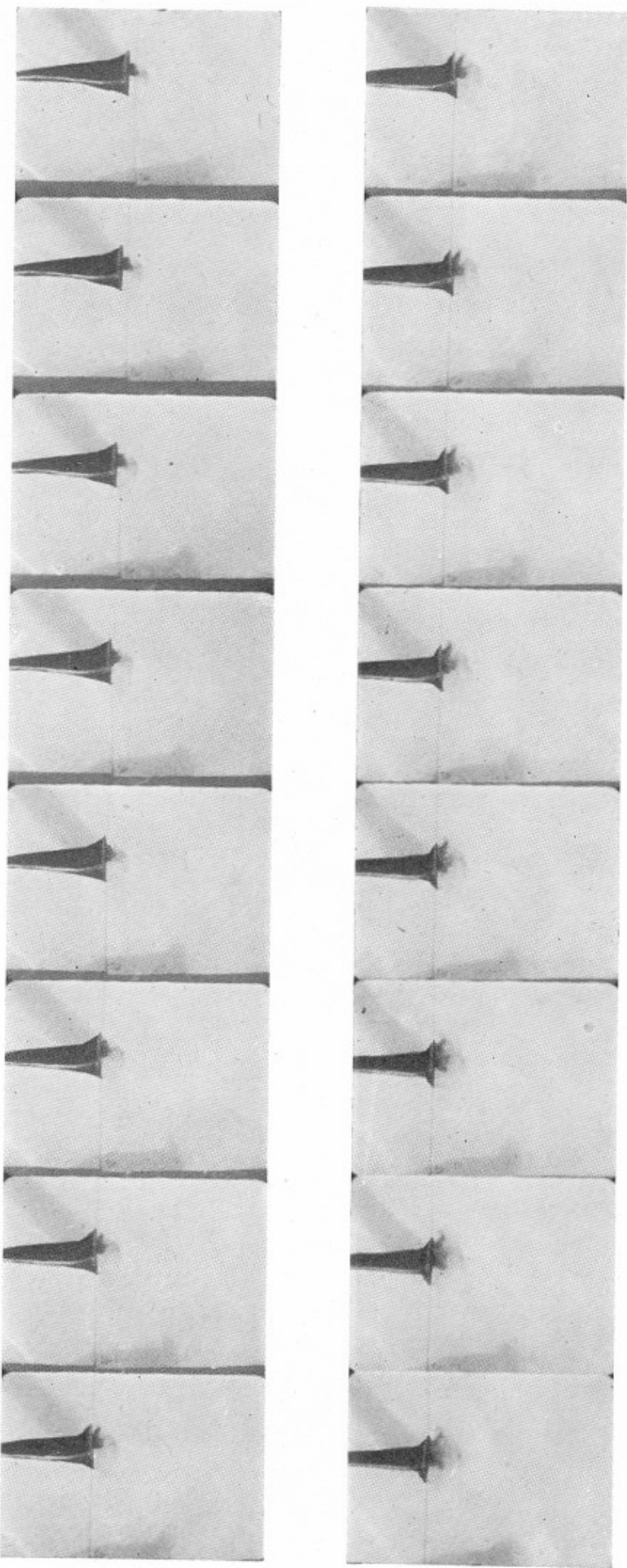